\title{
Pavlovian conditioning of the proboscis extension reflex in harnessed foragers using paired vs. unpaired and discrimination learning paradigms: tests for differences among honeybee subspecies in Turkey*
}

\author{
Charles I. Abramson ${ }^{1}$, T. Andrew MiXson ${ }^{1}$, Ibrahim ÇAKMAK ${ }^{2}$, Aaron J. PlacE ${ }^{3}$, \\ Harrington WELLS ${ }^{4}$ \\ ${ }^{1}$ Laboratory of Comparative Psychology and Behavioral Biology, Departments of Psychology and Zoology, \\ Oklahoma State University, 215 N. Murray, Stillwater, OK 74078, USA \\ ${ }^{2}$ Uludag Universitesi, M. Kemalpasa MYO, M. Kemalpasa, Bursa 16500, Turkey \\ ${ }^{3}$ Northwestern Oklahoma State University, Department of Natural Sciences, Alva, Oklahoma 73717, USA \\ ${ }^{4}$ University of Tulsa, Department of Biology, Tulsa, OK 74104, USA
}

Received 5 November 2007 - Revised 15 February 2008 - Accepted 3 March 2008

\begin{abstract}
Experiments utilized three honeybee subspecies from very distinct biomes (Apis mellifera caucasica, A.m. carnica, A.m. syriaca). In experiment one a simple association between odor and a sucrose feeding was readily established in all three subspecies. This association decreased when the conditioned stimulus was no longer followed by a feeding. Neither the learning rate nor extinction rate differed among subspecies. Unpaired controls confirmed that the acquisition of the odor-food association is learned. In experiment two, an attempt to uncover subspecies differences was tested through the ability of bees to discriminate between two odors, one of which is paired with a feeding. Rapid learning occurred in all subspecies and no significant subspecies differences were observed. Finally, discrimination learning was used as an added control to test for honeybee response to an olfactory versus mechanical (air) stimulus.
\end{abstract}

Proboscis conditioning / discrimination learning / Apis mellifera caucasica / Apis mellifera carnica / Apis mellifera syriaca

\section{INTRODUCTION}

Comparative studies have contributed greatly to our understanding of the evolution of cognitive processes (Smith et al., 2003). The European honeybee has been widely used as an invertebrate model system to investigate questions concerning anatomy, physiology, cognitive processes and social interaction (e.g. Ribbands, 1953; Snodgrass, 1956; von Frisch, 1993; Chittka and Wells, 2004; Abramson

Corresponding author: C.I. Abramson, charles.abramson@okstate.edu

* Manuscript editor: Stan Schneider et al., 2007). Although morphologically quite diverse (Ruttner, 1988), there are surprisingly few comparative investigations of learning using this model system. In part this is due to the endemic nature of honeybee subspecies, and widespread hybridization and introgression where subspecies have been introduced. In addition, insect cognition models have treated bees even in taxa as diverse as bumblebees and honeybees as essentially the same (e.g. Leadbeater and Chittka, 2007).

Nevertheless, some evidence suggests that significantly different cognition processes occur among bee taxa when faced with the same problem. First, the 'individual constancy' 
response of honeybee foragers (Hill et al., 1997, 2001; Sanderson et al., 2006) has not been reported in bumblebees, even in side by side tests using honeybees and bumblebees (Gegear and Laverty, 2004). Second, foraging differences among honeybee subspecies using the same artificial flower patch design under field conditions has been reported (Çakmak et al., 1998, 1999; Çakmak and Wells, 1996, 2001). Similar observations have been made with bumblebee species (Chittka et al., 2001). Third, Africanized honeybees in Brazil show lower levels of learning using a simple Pavlovian association between an odor and reward when compared to their European counterparts tested at the same time. This Africanized bee difference in the level of learning is seen when various types of conditioned stimuli are tested and when learned responses to pesticides are considered (Abramson et al., 1997; 1999, 2006, 2007; Abramson and Aquino, 2002; Aquino et al., 2004).

Proboscis conditioning has become a standard technique for the study of learning in honeybees (see Byrne, 2003 for reviews). The proboscis extension reflex technique was first described by Frings (1944) and refined over the years by Kuwabara (1957), Takeda (1961), Vareschi (1971), Bitterman et al. (1983) and Abramson and Boyd (2001). The reflex has been used in acquisition and extinction of a simple Pavlovian association between the odor and a food unconditioned stimulus and in discrimination tasks. Discrimination learning has several virtues when combined with an analysis of simple Pavlovian conditioning. It provides confirmation of the existence of learning using a within subject design. Also, since honeybees will associate not only an odor with a food but also changes in air pressure alone (wind) which is independent of the odor (unpublished data of Abramson), discriminate tests between two odors act as a control since change in air pressure over the antennae is the same and the odors are different.

Here we examine whether the foraging behavior differences reported under field conditions for subspecies of Apis mellifera are grounded in basic differential learning abilities.

\section{MATERIALS AND METHODS}

\subsection{Subjects}

There are at least five subspecies of A. mellifera L. that are endemic to different habitats in Turkey (Kandemir et al., 2000). Three honeybee subspecies that are endemic to distinct ecological regions in Turkey were tested for learning differences. A. $m$. syriaca is endemic to the hot, arid southeast of Turkey, while A. m. caucasica is from the northeast mountainous regions of turkey that experience long winters and cool, rainy summers. A. m. carnica is endemic to the Therese region of Turkey which experiences warm summers and mild winter.

Experiments were performed at the Middle Eastern Technical University (Orta Dogu Teknik Üniversitesi), Ankara, Turkey. The laboratory in which these experiments were conducted maintains pure lines of each subspecies for research purposes. Colonies were obtained from breeders in eastern Turkey near the Republic of Georgia, European Turkey near Bulgaria and southeast Turkey near Syria from government controlled areas specifically reserved for maintaining pure lines of each subspecies. The subspecies of each colony was confirmed using DNA restriction polymorphism analysis (Kandemir et al., 2006).

All experiments were conducted during June and July of 2007. To control for calendar variables and fluctuating hive conditions, animals from all experiments were run simultaneously and selected from multiple laboratory hives contained within the apiary.

\subsection{Apparatus and stimuli}

The conditioned stimulus (CS) in the simple Pavlovian experiments was the odor cinnamon (cinnamon oil: Gilbertie's, Easton, CT, USA). For the discrimination experiments we used the odor wintergreen (wintergreen oil: Gilbertie's, Easton, CT, USA) as well as cinnamon. The unconditioned stimulus (US) in all experiments was a $1.8 \mathrm{M}$ sucrose solution. The US was administered to the honeybee by dipping the tip of a $5 \mathrm{~mm} \times 3 \mathrm{~mm}$ filter paper strip (Whatman \# 4) into the solution and applying the paper first to the antennae, and then to the now extended proboscis.

Approximately $3 \mu \mathrm{L}$ of an essential oil (cinnamon or wintergreen) was applied each day to a new $1 \mathrm{~cm}^{2}$ piece of filter paper (Whatman No. 4) 
attached to a $20 \mathrm{~mL}$ plastic syringe to create a CS odor cartridge. To apply the CS, the plunger of the syringe was pulled back to the $20 \mathrm{~mL}$ mark and quickly depressed. Prior research designed to directly compare automated and unautomated proboscis conditioning techniques revealed no differences in conditioning (Abramson and Boyd, 2001).

\subsection{Procedure}

For the proboscis conditioning experiments, foraging honeybees were captured in glass vials from laboratory hives, placed in an ice water bath, and while inactive harnessed in metal tubes. Once active, they were fed $1.8 \mathrm{M}$ sucrose solution until satiated and set aside for use approximately 24 hours later. Only those animals that vigorously extended their proboscis to sucrose stimulation during a pretest were used in experiments.

All proboscis-conditioning experiments used a CS duration of $3 \mathrm{~s}$ and a US duration of approximately $2 \mathrm{~s}$. A conditioning trial began by picking up a bee and placing it in a fume hood, after which the appropriate stimuli were introduced. After application of the stimuli, the animal was returned to a holding area and a second animal was run. A trace conditioning procedure was used where the CS was presented first followed by the US. The CS and US presentations did not overlap. If the animal extended its proboscis during the CS but before the US a ' 1 ' was recorded. If the proboscis did not extend to the CS ' 0 ' was recorded. Responses were recorded from visual observations.

\subsection{Experiment 1: simple Pavlovian conditioning}

The experiment tested 40 bees from each subspecies $(N=120)$. Within each of the three subspecies groups of 40 bees each, 20 bees received paired CS-US presentations (paired treatment) and 20 bees received unpaired CS/US presentations (unpaired treatment). Bees were randomly chosen with respect to treatment received.

Paired treatment bees all received 12 acquisition trials with paired CS-US. This was followed by 12 extinction trials in which the US was omitted. The intertrial interval (ITI) was $10 \mathrm{~min}$ in each case. Extinction trials were included to determine whether subspecies differences could be detected by their persistent response in the absence of the US.
Unpaired treatment bees received 12 CS presentations and 12 US presentations in a pseudorandom order. Stimulus presentations for 10 bees consisted of three successive sequences of CS US US CS US CS CS US. The remaining 10 bees received three successive sequences of US CS CS US CS US US CS. The interval between stimulus presentations for unpaired treatment bees was $5 \mathrm{~min}$, which was half the time used for the paired treatment. A 5 min ITI for unpaired treatments was used in order to have a $10 \mathrm{~min}$ time between CS presentations. If a $10 \mathrm{~min}$ ITI was used, the time between CS presentations would be $20 \mathrm{~min}$ and any difference between paired and unpaired animals learning rates could be due to non-associative effects of the time spent harnessed. Following the $12 \mathrm{CS}$ and 12 US presentations, the unpaired experiment was terminated (no extinction trials).

\subsection{Experiment 2: discrimination conditioning}

The designed differed from that used in the simple learning experiment in that two CSs were used, but only one CS was paired with the US. Extinction trials were not tested. In addition, there was no unpaired treatment since in discrimination experiments each subject served as its own control.

One CS was cinnamon scent used in the simple learning experiments and the second was the odor of wintergreen. The CS in an experiment that was followed by the US is denoted as CS+ and the CS in an experiment not followed by the US is denoted as CS-. The CS+ was cinnamon for half of the bees and the CS- was wintergreen; for the remaining animals the $\mathrm{CS}+$ was wintergreen and the CS- cinnamon.

The experiment tested 20 bees from each subspecies $(\mathrm{N}=60)$. Acquisition consisted of 12 presentations of both the CS+ and CS- so that a total of 24 trials were conducted. The presentation of the CSs consisted of three successive sequences of $\mathrm{CS}+\mathrm{CS}-\mathrm{CS}-\mathrm{CS}+\mathrm{CS}-\mathrm{CS}+\mathrm{CS}+\mathrm{CS}-$. As in the previous experiment a non-overlap procedure was used. A 5 min ITI was used in the discrimination experiments in order to keep the time between $\mathrm{CS}+$ presentations approximately $10 \mathrm{~min}$. If a $10 \mathrm{~min}$ ITI was used, the time between $\mathrm{CS}+$ presentations would be approximately $20 \mathrm{~min}$, and any difference between our simple and complex learning experiments could be due to non-associative effects such as time spent harnessed. Responses to the CS were 


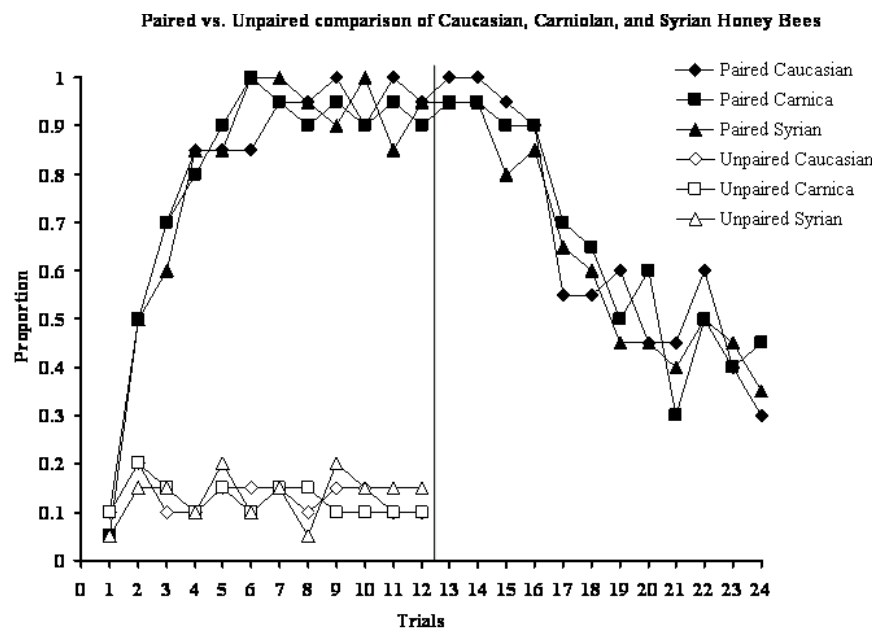

Figure 1. Performance of paired and unpaired animals. The transition from acquisition to extinction occurs on trial 13.

visually categorized into 1 of 2 states during each trial. If a subject extended its proboscis after the onset of the CS, but before the US was presented, a response was recorded ("1"). Otherwise, a nonresponse was recorded ("0").

\section{RESULTS}

\subsection{Statistical methods}

Each of the experiments conducted consisted of 12 or 24 repeated measures on each of 20 individual bees. A multivariate analysis of variance approach to repeated measures was utilized. To test for trial and group effects, a general linear model with each trial and species as independent variables and the proboscis extension reflex as the dependent variable was generated. Analyzing dichotomous data with the $\mathrm{F}$ statistic is questionable. However, Winer et al. (1991) citing Cochran (1950), suggest that the probability statements yielded by F-tests are relatively similar to those yielded by equivalent non-parametric tests. Test statistics are reported along with estimates of effect size and observed power.

\subsection{Experiment 1: simple Pavlovian conditioning}

A.m. caucasica, A.m. carnica and A.m. syriaca all rapidly learned to associate the odor of cinnamon with the sucrose reward (Fig. 1). The proportion of animals responding to the CS begins low and increases over the course of acquisition training. During the extinction phase in which the US is no longer presented, the proportion of conditioned responses decrease. The consistently low proportion of animals responding to unpaired presentations of the CS and US indicates that the performance of the paired animals is due to learning. Statistical analyses support these conclusions.

A multivariate analysis of variance with trial as a within subjects repeated factor and sub-species and treatment (paired vs. unpaired) as between subjects factors revealed no significant trial $\times$ species $\times$ treatment interaction (Wilk's $\lambda=0.857, \mathrm{~F}_{22,208}=0.767$, $P=0.771, \eta^{2}=0.074$, Power $\left.=0.606\right)$. Similarly there was no significant trial $\times$ species interaction (Wilk's $\lambda=0.935, \mathrm{~F}_{22,208}=0.325$, $P=0.998, \eta^{2}=0.033$, Power $=0.245$ ). The interaction between trial and treatment was significant (Wilk's $\lambda^{2}=0.306, \mathrm{~F}_{11,104}=$ 21.458, $P<0.0001, \eta^{2}=0.694$, Power $=$ 1.00) indicating a difference between paired and unpaired subject learning rate. There was no significant treatment by species interaction $\left(\mathrm{F}_{2,57}=0.017, P=0.983, \eta^{2}=0.0003\right.$, Power $=0.052$ ).

A similar general linear model was constructed for the extinction trials with repeated measures occurring on trials 13-24 to assess 


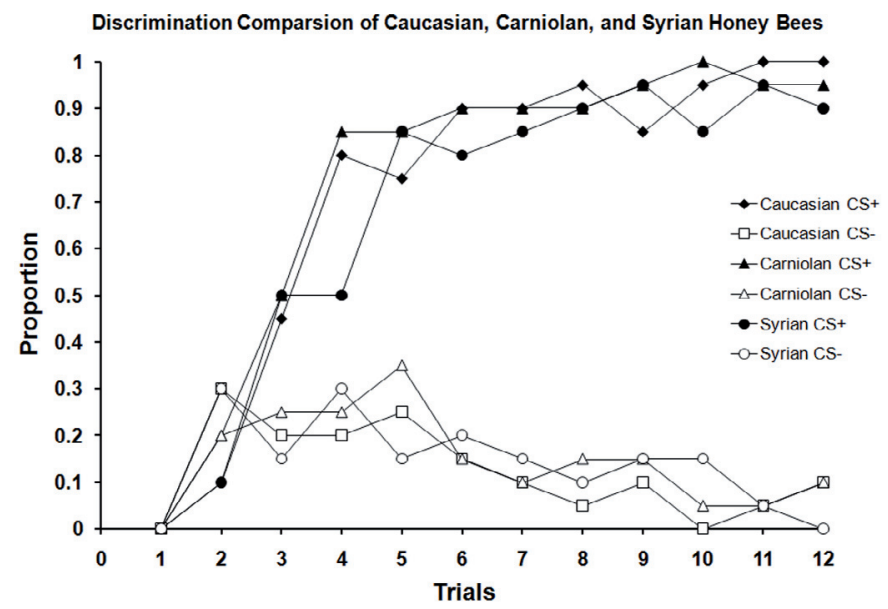

Figure 2. Performance of animals trained to discriminate among two conditioned stimuli one of which $(\mathrm{CS}+)$ is paired with a sucrose reward and the other (CS-) is not.

extinction. There was no significant trial $\times$ species interaction (Wilk's $\lambda=0.745, \mathrm{~F}_{20,96}=$ $0.760, P=0.753, \eta^{2}=0.137$, Power $\left.=0.534\right)$. There was a significant trial effect (Wilk's $\lambda=0.285, \mathrm{~F}_{10,48}=12.046, P<0.0001$, $\eta^{2}=0.715$, Power $\left.=1.00\right)$. There was no significant difference among species in extinction rate $\left(\mathrm{F}_{2,57}=0.01, P=0.905, \eta^{2}=0.003\right.$, Power $=0.064)$.

\subsection{Experiment 2: discrimination conditioning}

A.m. caucasica, A.m. carnica, and A.m. syriaca also rapidly learn to discriminate between the $\mathrm{CS}+$ and CS- odors (Fig. 2). As discrimination training continues, animals from all three sub-species clearly differentiate between a CS that is associated with the reward from one that is not. Statistical analyses support these visual observations.

A multivariate analysis of variance with trial as a within-subjects repeated factor and treatment (CS+ vs. CS-) and species as between subjects factors indicated no significant interaction between trial $\times$ species $\times$ treatment (Wilk's $\lambda=0.806, \mathrm{~F}_{22,208}=1.074, P=0.378$, $\eta^{2}=0.1 .8$, Power $\left.=0.802\right)$. Likewise, the interaction between trial and species was not significant (Wilk's $\lambda=0.880, \mathrm{~F}_{22,208}=0.624$, $P=0.904, \eta^{2}=0.062$, Power $\left.=0.497\right)$, nor was the treatment $\times$ species interaction $\left(\mathrm{F}_{2,119}=0.651, P=0.524, \eta^{2}=0.011\right.$, Power $=0.157)$. The interaction trial $\times$ treatment was significant (Wilk's $\lambda=0.369, \mathrm{~F}_{11,104}=$ 16.193, $P<0.0001, \eta^{2}=0.631$, Power $=$ 1.00 ) indicating that a significant difference between the CS+ and CS-groups.

\section{DISCUSSION}

Proboscis conditioning of harnessed bees is part of a general strategy in the search for potential honeybee subspecies differences in learning ability. Experiments with free-flying foragers may also yield such differences. If such differences indeed exist, particular subspecies may be better suited for different pollination tasks.

The experiments reported here should be considered as a first attempt to discover subspecies differences. Comparative investigations are never easy to perform and differences may yet be detected when variables such as age and task complexity are manipulated (Hammer and Menzel, 1995). Our rationale for the selection of paired vs. unpaired and discrimination tasks were two-fold. First, we have used such paradigms in anticipation of the examination of agro-chemicals on honeybee learning (e.g., Abramson et al., 2006). 
The proboscis extension reflex has become a valuable tool in the study of agro-chemicals (Desneux et al., 2007) and we will be conducting agro-chemical research in Turkey similar to what we have done in Brazil.

We also have interest in these paradigms as a comparative tool. Now that it is established that paired and discrimination paradigms can provide lawful data in harnessed A.m. caucasica, A.m. carnica, and A.m. syriaca foragers, we can expand these paradigms to include more complex procedures such as the use of reversal learning where, for instance, a CS+ is turned into a CS- and a CS- turned into a CS+ and the rapidity of adjustment is used as the dependent variable (Ben-Shahar et al., 2000). Latent inhibition in which a pre-exposed CS is subsequently paired with a US may also yield subspecies differences (Abramson and Bitterman, 1986; Chandra et al., 2000) as might the effect of punishment (Smith et al., 1991). Clearly, there is much work to be done in an attempt to find subspecies differences.

The results of the simple Pavlovian conditioning experiments and those related to discrimination clearly show that A.m. caucasica, A.m. carnica and A.m. syriaca all learned rapidly, and extinction occurred when the CS no longer was associated with the sucrose reward. Also, workers of all three subspecies readily discriminated between CS scents and associated the reward with the CS+. Learning was verified by the use of the unpaired treatment and discrimination learning as experimental controls. The discrimination learning experiments also assured that animals were responding to the odors of cinnamon and wintergreen rather than the effect of air alone blowing over the antennae. Without such training it cannot be unequivocally concluded that animals are responding to an olfactory CS. Clearly the harnessing procedure utilized did not render bees unable to learn.

Given the experimental design, there is little reason to believe that differences in learning rate based on simple Pavlovian conditioning exist among the subspecies tested. Neither do the data support a model where association of cause and effect are retained for different lengths of time among honeybee subspecies. Although limited to two particular odors, our data also do not support the different discrimination abilities among honeybee subspecies. Nevertheless, some honeybee behavioral differences reported are undoubtedly subspecies related. For example, there is no doubt that Africanized honeybees are more aggressive than their European counterparts in any location (e.g. Spivak et al., 1991). Similarly, hygienic behavior is known to be a genetically controlled trait (e.g. Moritz, 1988), and differences in brood versus honey production among subspecies are also well established (e.g. Ruttner, 1988). These observations, when combined with the data presented here, thus suggest a hierarchial cognitiveprocesses in honeybees where the fundamental abilities do not differ among subspecies, but abilities are utilized differently. However, foraging differences reported among honeybee subspecies (Çakmak et al., 1998, 1999; Çakmak and Wells, 1996, 2001) and among bumblebee species (Chittka et al., 2001) may still be due to habitat or genetics because they are reports from observation of bees at particular localities, albeit under standardized conditions. Further studies are needed in order to choose among these competing theories.

In conclusion, differences in behavior are seen among some subspecies of honeybee. However, we have little information of how these differences are manifested. This paper takes the first step in understanding differences in a Turkish sample by testing whether behaviors originate from very basic learning abilities. We believe that an understanding of the basic learning processes in honeybees is the key to understanding any differences in cognitive architectures and we show, interestingly, that differences are not at the most basic levels of Pavlovian learning.

\section{ACKNOWLEDGEMENTS}

Participation of Mixson was supported by a Research Experience for Undergraduate grant from the National Science Foundation (DBI 0552717) additional support for Mr. Mixson was provided by NIH-IMSD grant\# 5R25GM069516. We would like to express our deep appreciate to Dr.'s Aykut and Meral Kence for providing laboratory facilities, and to Dr. Tugrul Giray for proving access to the apiary. 
Conditionnement pavlovien du réflexe d'extension du proboscis chez des butineuses en contention à l'aide de paradigmes appariés et non appariés pour l'apprentissage discriminatoire : tests de différences parmi les sous-espèces d'abeilles domestiques en Turquie.

Apis mellifera caucasica / Apis mellifera carnica / Apis mellifera syriaca / conditionnement / extension du proboscis / apprentissage / discrimination

Zusammenfassung - Pawlowsche Konditionierung des Rüsselreflexes bei fixierten Sammlerinnen mit verbundenen und unverbundenen Ansätzen für diskriminatorisches Lernen: Test auf Unterschiede zwischen Bienenrassen in der Türkei. Die Effektivität der RüsselreflexKonditionierung in drei Honigbienen-Rassen wurde in der Zentraltürkei untersucht. Obwohl die Bienen sich morphologisch stark unterscheiden, gibt es bisher erstaunlich wenig vergleichende Untersuchungen zum Lernverhalten.

Aus zwei Gründen konzentrierten wir uns bei unseren ersten Untersuchungen auf einfaches diskriminatives Lernen. Erstens hatten wir solche Lernversuche in einigen früheren Studien zur Wirkung von Pestiziden auf Honigbienen verwendet. Zweitens helfen diskriminative Experimente bei der weiteren Interpretation des Lernens, da z. B. der Wind, der beim Anbieten von Duftstoffen über Luftströme erzeugt wird, per se als konditionierender Reiz wirken kann. In diskriminativen Lernversuchen müssen die Bienen auf einen von zwei angebotenen Düften reagieren, während der Wind, der während der Duftstoffapplikation erzeugt wird, konstant gehalten wird. Ohne diese diskriminative Kontrolle könnte man nicht sicher sein, dass die Biene auch wirklich auf den vermeintlichen Duft als Konditionierungsreiz reagiert. Diskriminative Experimente ermöglichen auch komplexere Versuchsanordnungen wie z. B. Reversal-Lernen.

In Experiment 1 wurden 40 Bienen aus verschiedenen Völkern von Apis mellifera caucasica, A.m. carnica und A.m. syriaca getestet. Innerhalb jeder Bienenrasse erhielten 20 Bienen je 12 verbundene KS-US angeboten (KS = konditionierender Stimulus, US = unkonditionierender Stimulus) angeboten und danach 12 Extinktionsversuche, in denen der US ausgelassen wurde. Die Extinktionsversuche sollten Aufschluss über die Dauerhaftigkeit der Reizantwort innerhalb der einzelnen Bienenrassen geben. Als Kontrolle für Pseudokonditionierung erhielt eine zweite Gruppe von Bienen unverbundene KS-US angeboten. Die Dauer des KS war 3 Sekunden, die des US 2 Sekunden und das Intervall zwischen den Versuchsdurchgängen (ITT) betrug 10 Minuten.

Das zweite Experiment unterschied sich vom ersten lediglich dadurch, dass zwei konditionierende Stimuli (KS) angeboten wurden, die Extinktion nicht untersucht wurde und ITT von 10 auf 5 Minuten reduziert wurde. Von 20 Bienen jeder Rasse erhielten die Hälfte KS+ (Zimt) und einen KS(Wintergrün) ohne anschließendes Füttern. Für die restlichen 10 Bienen jeder Gruppe wurden die Düfte für CS+ und CS- in umgekehrter Reihenfolge angeboten.

Bei den Ergebnissen konnten keine Unterschiede zwischen den drei Bienenrassen festgestellt werden. Die Abbildung 1 zeigt, dass die Lernkurven für Apis mellifera caucasica, A.m. carnica, und A.m. syriaca sowohl in der Lern- als auch in der Extinktionsphase ähnlich sind. Die Abbildung 2 bestätigt darüber hinaus, dass alle drei Bienenrassen rasch zwischen den zwei KS unterscheiden können und es dabei keine Rassenunterschiede gibt.

Obwohl wir keine Rassenunterschiede bei der einfachen und diskriminativen Konditionierung feststellen konnten, ist diese Rüsselreflex-Konditionierung nur ein erster Schritt bei der Untersuchung potentieller Unterschiede in der Lernfähigkeit verschiedener Bienenrassen. Laufende Untersuchungen an frei fliegenden Sammlerinnen mögen hier weitere Aufschlüsse bringen. Sollten Lernunterschiede tatsächlich existieren, könnten sich bestimmte Bienenrassen besser für Bestäubungsmaßnahmen eignen als andere.

Rüsselreflex-Konditionierung / Diskriminatives Lernen / Apis mellifera caucasica / Apis mellifera carnica / Apis mellifera syriaca

\section{REFERENCES}

Abramson C.I., Bitterman M.E. (1986) Latent inhibition in honey bees, Anim. Learn. Behav. 13, 184 189.

Abramson C.I., Boyd B.J. (2001) An automated apparatus for conditioning proboscis extension in honey bees (Apis mellifera L.), J. Entomol. Sci. $36,78-92$.

Abramson C.I., Aquino I.S. (2002) Behavioral studies of learning in the Africanized honey bee (Apis mellifera L.), Brain Behav. Evolut. 59, 68-86.

Abramson C.I., Aquino I.S., Silva M.C., Price J.M. (1997) Learning in the Africanized honey bee: Apis mellifera L., Physiol. Behav. 62, 657-674.

Abramson C.I., Aquino I.S., Ramalho F.S., Price J.M. (1999) Effect of insecticides on learning in the Africanized honey bee (Apis mellifera L.), Arch. Environ. Con. Tox. 37, 529-535.

Abramson C.I., Singleton J.B., Wilson M.K., Wanderley P.A., Ramalho F.S., Michaluk L.M. (2006) The effect of an organic pesticide on mortality and learning in Africanized honey bees (Apis mellifera L.) in Brasil, Am. J. Environ. Sci. 2, 37-44.

Abramson C.I., Wells H., Bozic J. (2007) Social insect model for the study of ethanol induced behavior: The honey bee, in: Yoshida R. (Ed.), Trends in Alcohol Abuse and Alcoholism Research, Nova Science Publishers, Hauppauge, New York, pp. 197-218. 
Abramson C.I., Wanderley P.A., Wanderley M.J.A., Silva J.C.R., Michaluk L.M. (2007) The effect of Sweet Fennel and Pignut on the mortality and learning of Africanized honey bees (Apis mellifera L.) in Brazil, Neotrop. Entomol. 36, 828-835.

Aquino I.S., Abramson C.I., Soares A.E., Fernandez A.C., Benbassat D. (2004) Classical conditioning of proboscis extension in harnessed Africanized honey bee queens (Apis mellifera L.), Psychol. Rep. 94, 1163-1174.

Ben-Shahar Y., Thompson C.K., Hartz S.M., Smith B.H., Robinson G. (2000) Differences in performance on a reversal learning test and division of labor in honey bee colonies, Anim. Cogn. 3, 119125.

Bitterman M.E., Menzel R., Fietz A., Schäfer S. (1983) Classical conditioning of proboscis extension in honeybees (Apis mellifera), J. Comp. Psychol. 97, $107-119$.

Byrne J.H. (2003) Learning and memory, 2nd ed., MacMillan, NY.

Çakmak I., Wells H. (1996) Flower color, nectar reward and flower fidelity of Caucasian honey bee (Apis mellifera caucasica), Turk. J. Zool. 20, 389396.

Çakmak I., Wells H. (2001) Reward frequency: effects on flower choices made by different honey bee races in Turkey, Turk. J. Zool. 25, 169-176.

Çakmak I., Firatli Ç., Wells H. (1998) The response of Apis mellifera syriaca and A.m. armeniaca to nectar differences, Turk. J. Agric. For. 22, 561571.

Çakmak I., Cook P., Hollis J., Shah N., Huntley D., Valkenburg D., Wells H. (1999) Africanized honey bee forager responses to flower colour correlated reward frequency differences, J. Apicult. Res. 38, $125-136$.

Chandra S.B.. Hosler J.S., Smith B.S. (2000) Heritable variation for latent inhibition and its correlation with reversal learning in honeybees (Apis mellifera), J. Comp. Psychol. 114, 86-97.

Chittka L., Wells H. (2004) Color vision in bees: mechanisms, ecology and evolution, in: Prete F. (Ed.), Complex worlds from simpler nervous systems, MIT Press, Cambridge, Massachusetts, pp. 165191.

Chittka L., Spaethe J., Schmidt A., Hickelsberger A. (2001) Adaptation, constraint, and chance in the evolution of flower color and pollinator color vision, in: Chittka L., Thomson J.D. (Eds.), Cognitive ecology of pollination, Cambridge University Press, Cambridge, Massachusetts, pp. 106-126.

Cochran W.G. (1950) The comparison of percentages in matched samples, Biometrika, 37, 256-266.

Desneux N., Decourtye A., Delpuech J. (2007) The sublethal effects of pesticides on beneficial arthropods, Annu. Rev. Entomol. 52, 81-106.

Frings H. (1944) The loci of olfactory end-organs in the honeybee, J. Exp. Zool. 97, 123-134.

Frisch K. von (1993) The dance language and orientation of bees, Harvard University Press, Harvard, Massachusetts.
Gegear R.J., Laverty T.M. (2004) Effect of a colour dimorphism on the flower constancy of honey bees and bumble bees, Can. J. Zool. 82, 587-593.

Hammer M., Menzel R. (1995) Learning and memory in the honeybee, J. Neurosci. 15, 1617-1630.

Hill P.S., Wells P.H., Wells H. (1997) Spontaneous flower constancy and learning in honey bees as a function of colour, Anim. Behav. 54, 615-627.

Hill P.S., Hollis J., Wells H. (2001) Flower constancy to colour in honeybees (Apis mellifera ligustica) when interfloral distances are varied, Anim. Behav. 62, 729-737.

Kandemir I., Kence M., Kence A. (2000) Genetic and morphometric variation in honeybee (Apis mellifera L.) populations of Turkey, Apidologie 31, 343-356.

Kandemir I., Kence M., Sheppard W.S., Kence A. (2006) Mitochondrial DNA variation in honeybee (Apis mellifera L.) populations from Turkey, J. Apic. Res. 45, 33-38.

Kuwabara M. (1957) Bildung des bedingten Reflexes vom Pavlov Typus bei der Honigbiene, Apis mellifera [Establishment of Pavlovian conditioned reflexes in honeybees], J. Sci. Hokkaido Univ. Zool. 13, 458-464.

Leadbeater E., Chittka L. (2007) Social learning in insects - From miniature brains to consensus building, Curr. Biol. 17, 703-713.

Moritz R.F.A. (1988) A reevaluation of two locus model for hygienic behavior in honey bees (Apis mellifera L.), J. Hered. 79, 257-262.

Ribbands C.R. (1953) The behaviour and social life of honeybees, Bee Research Association, London.

Ruttner F. (1988) Biogeography and taxonomy of honeybees, Springer-Verlag, New York.

Sanderson C.E., Orozco B.S, Hill P.S.M., Wells H. (2006) Honeybee (Apis mellifera ligustica) response to differences in handling time, rewards, and flower colours, Ethology 112, 937-946.

Smith B.H., Abramson C.I., Tobin T.R. (1991) Conditioning withholding of proboscis extension in honey bees (Apis mellifera) during discriminate punishment, J. Comp. Psychol. 105, 345-356.

Smith D.J., Shields W.E., Washburn D.A. (2003) The comparative psychology of uncertainty monitoring and metacognition, Behav. Brain Sci. 26, 317339.

Snodgrass R.E. (1956) Anatomy of the honey bee, Cornell University Press, Ithica, New York.

Spivak M., Fletcher D.J.C., Breed M.D. (1991) The "African" honey bee, Westview Press, San Francisco, California.

Takeda K. (1961) Classical conditioned response in the honeybee, J. Insect Physiol. 6, 168-179.

Vareschi E. (1971) Duftunterscheidung bei der Honigbiene: Einzellzell-Ableitungen und Verhaltensreaktionen [Odor discrimination by the honeybee: Single cell recording and behavior reaction], Z. Vergl. Physiol. 75, 143-173.

Winer B.J., Brown D.R., Michels K.M. (1991) Statistical principles in experimental design, 2nd ed., McGraw-Hill, New York. 